\title{
Evaluation of antibacterial and antifungal compounds for selective inhibition of denitrification in soils
}

\section{AUTHORS:}

Shiva Ladan ${ }^{\mathrm{a}}$, Pierre-André Jacinthe $\mathrm{a}^{\mathrm{a}^{*}}$

\begin{abstract}
ADDRESSES OF AUTHORS:
aDepartment of Earth Sciences, Indiana University Purdue University, Indianapolis, IN 46202
\end{abstract}

\section{CORRESPONDING AUTHOR:}

*Dr. Pierre-André Jacinthe

Department of Earth Sciences

Indiana University Purdue University Indianapolis (IUPUI)

723 W. Michigan Street, SL 118

Indianapolis, IN 46202

Phone: (317) 274-7969; Fax: (317) 2747966

E-mail: pjacinth@iupui.edu

This is the author's manuscript of the article published in final edited form as:

Ladan, S., \& Jacinthe, P. A. (2016). Evaluation of antibacterial and antifungal compounds for selective inhibition of denitrification in soils. Environmental Science: Processes \& Impacts, 18(12), 1519-1529. https://doi.org/10.1039/c6em00456c 


\begin{abstract}
Nitrous oxide $\left(\mathrm{N}_{2} \mathrm{O}\right)$ is an atmospheric constituent implicated in climate warming and stratospheric ozone depletion. Both bacteria and fungi participate in $\mathrm{N}_{2} \mathrm{O}$ production, but information is lacking with regard to the relative contribution of bacterial and fungal denitrifiers to the denitrification process in agricultural soils. The selective inhibition technique (SI) is widely used to assess the contribution of different groups of microbes to soil processes, but success of the technique depends on the effectiveness of the inhibitors. In this study, laboratory experiments were conducted to assess the contribution of bacteria and fungi to denitrification using soils from a woodlot, agricultural fields under conventional plowing (PT), and no-till for either 50 years (long-term) or 11 years (medium-term). A selective inhibition (SI) technique was developed using two bactericides (streptomycin, bronopol) and two fungicides (cycloheximide, captan) applied at different rates (0-32 $\mathrm{mg} \mathrm{g}^{-1}$ soil). Regardless of application rate, streptomycin and cycloheximide were not effective inhibitors of denitrification, with degree of inhibition only between 2 and $20 \%$ relative to controls. These results are significant given the wide use of these products in SI studies. However, the bactericide bronopol and the fungicide captan effectively inhibited denitrification, with the strongest inhibition observed at an application rate of $16 \mathrm{mg} \mathrm{g}^{-1}$ soil. The ratio of fungal to bacterial denitrification activity (F:B) was generally less than 1 , indicating a dominance of bacteria in denitrification activity in the soils investigated. However, an increase in F:B ratio from 0.24 in mediumterm NT to 0.87 in long-term NT soils was noted, suggesting perhaps a progressive increase in the role of fungal denitrifiers with longer duration of NT farming.
\end{abstract}




\section{Introduction}

Nitrous oxide $\left(\mathrm{N}_{2} \mathrm{O}\right)$ is a by-product of nitrogen $(\mathrm{N})$ cycling processes in soil ecosystems, and an important atmospheric constituent implicated in the accelerated greenhouse effect and stratospheric ozone depletion. ${ }^{1}$ Although $\mathrm{N}_{2} \mathrm{O}$ can also originate from nitrification, denitrification remains the dominant $\mathrm{N}_{2} \mathrm{O}$ production process in soils. ${ }^{1}$ Denitrification is the dissimilatory reduction of nitrate $\left(\mathrm{NO}_{3}^{-}\right)$to $\mathrm{N}_{2} \mathrm{O} / \mathrm{N}_{2}$ by mostly facultative anaerobes as a substitute for oxygen during respiration under oxygen-deficient conditions. ${ }^{1,2}$ As denitrifying microbes are largely heterotrophs, $\mathrm{N}_{2} \mathrm{O}$ production is often limited by the availability of metabolizable organic carbon. ${ }^{3}$

Both fungi and bacteria participate in $\mathrm{N}_{2} \mathrm{O}$ production in soils ${ }^{18}$, and therefore their relative contribution to the denitrification process can be affected by land-use and management. Among anthropogenic activities, agriculture has been identified as the largest contributor to global $\mathrm{N}_{2} \mathrm{O}$ emission, largely due to tillage operations and application of $\mathrm{N}$ fertilizers. ${ }^{4,5,6,7,8,9,10}$ No-till (NT) is a farming practice that has gained wide acceptance in recent decades, and has been proposed as an alternative to the conventional plow-till (PT) practice. In contrast to PT, the land surface remains relatively undisturbed under NT, and the current year's crop seeds are sown directly into the residue left by the previous crop. The effects of no-till farming on soil moisture, temperature, organic carbon (SOC) availability, size and composition of the soil microbial community are well documented. ${ }^{11}$ Several past studies have reported an increase in the fungi:bacteria ratio of the soil microbiota with NT adoption. ${ }^{2,11,12,13,14}$ It has been suggested that litter mixing with soil (and thus direct contact between the soil bacteria and substrate) caused by plowing creates conditions favorable to bacterial 
growth under PT. ${ }^{14}$ However, in NT systems in which there is a spatial separation between microorganisms and decomposable litter on the soil surface, the presence of hyphae confers an ecological advantage to fungi. ${ }^{15}$ Kladivko $^{16}$ suggested that higher soil moisture content under NT management may contribute to fungal dominance in the soil microflora. This shift in soil microbial community composition has been linked to SOC accretion, with land management practices favorable to fungal dominance generally resulting in enhanced SOC storage ${ }^{11,17}$, but it remains unclear whether a similar connection can be made with regard to denitrification in agricultural soils. Thus, an objective of this study was to assess the relative contribution of fungi and bacteria to denitrification in PT and NT soils (both medium- and long-term). It was hypothesized that, as the soil microbial community becomes fungal-dominated with longer duration of NT, there will be a parallel increase in the relative contribution of fungi to denitrification in agricultural soils.

To examine the role of fungi and bacteria in soil processes, different approaches have been adopted, but the selective inhibition (SI) has been the most widely-used technique. ${ }^{13,19}$ The technique was first introduced by Anderson and Domsch ${ }^{20}$ and was then modified for application to agricultural and forest soils. ${ }^{21}$ Different bactericides (e.g. streptomycin sulphate, bronopol and oxytetracycline) and fungicides (e.g. captan, cycloheximide, ketoconazole, benomyl and nystatin) have been employed in past studies $^{13,17,22,23,24}$, including studies investigating denitrification in soils and sediments. ${ }^{13}$, 25,26, 27,28 In these studies, different types of biocides were used and at different application rates. Inhibition efficiency has been variable, and after analysis of published results, it has not been possible to identify the type and the optimum concentration of biocide that is 
most inhibitory to denitrification in agricultural soils. Therefore, in this study, a standardized method was developed and applied to several US Midwest soils to determine the relative contribution of fungi and bacteria to denitrification.

\section{Materials and methods}

\section{Soil samples collection}

This study was conducted with soil samples $(0-10 \mathrm{~cm})$ collected from a farmer's fields in Indiana $\left(39^{\circ} 51^{\prime} 49^{\prime \prime} \mathrm{N}, 86^{\circ} 21^{\prime} 31^{\prime \prime} \mathrm{W}\right)$ and from experimental plots in Ohio $\left(39^{\circ} 51^{\prime} 48^{\prime \prime} \mathrm{N}\right.$, $\left.83^{\circ} 40^{\prime} 20^{\prime \prime} \mathrm{W}\right)(\mathrm{USA})$. Management practices included conventional tillage (PT 1 ), longterm no-till ( $\mathrm{NT}_{1}, 50$ years) at the Ohio plots, and included conventional tillage ( $\left.\mathrm{PT}_{2}\right)$ and medium-term no-till (NT2, 11 years) at the farmer's fields in Indiana. Soil samples were

also collected from a nearby deciduous forest (woodlot, WL), serving as a local relatively undisturbed site for comparison. The Ohio plots are under continuous corn (Zea mays, L.), and typically receive $16 \mathrm{~kg} \mathrm{~N} \mathrm{ha}^{-1}$ at planting and $184 \mathrm{~kg} \mathrm{~N} \mathrm{ha}^{-1}$ as anhydrous $\mathrm{NH}_{3}$ (side-dress). The farmer's fields in Indiana are under corn-soybean (Glycine max, L.) rotation. During the corn year, the fields receive $5-10 \mathrm{~kg} \mathrm{~N} \mathrm{ha}^{-1}$ at planting plus $150-180$ $\mathrm{kg} \mathrm{N} \mathrm{ha}^{-1}$ as anhydrous $\mathrm{NH}_{3}$. No $\mathrm{N}$ fertilizer is applied during the soybean crop. At the sampling sites, soils are classified as Crosby (aeric Epiaqualfs) and Brookston (typic Argiaquolls) developed from glacial till. Soil samples were transported to the laboratory in plastic bags, sieved $(2 \mathrm{~mm})$ and kept in a refrigerator $\left(4^{\circ} \mathrm{C}\right)$ until used in the experiments described below. A portion of each soil sample was air-dried and used for determination of chemical properties (Table 1). 


\section{Selection of fungal and bacterial denitrification inhibitors}

The selective inhibition (SI) technique ${ }^{21}$ was used with adaptation. First, a series of assays was conducted to identify the biocides (bactericide and fungicide), and application rates that yield maximum inhibition of denitrification. The tested biocides included some of the compounds most commonly used in past studies as well as some novel products. This evaluation was conducted using soil samples collected from the NT1 site (Table 1).

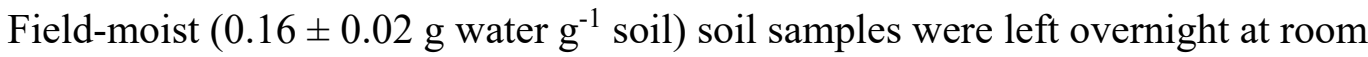
temperature $\left(22^{\circ} \mathrm{C}\right)$ in the laboratory for acclimation. Then, $10 \mathrm{~g}$ of soil subsamples were placed in serum bottles $(250 \mathrm{~mL})$ and amended with $1.44 \mathrm{ml}$ of denitrification enzyme activity (DEA) media (100 mg NO3-N kg-1 and $40 \mathrm{mg}$ dextrose- $\mathrm{C} \mathrm{kg}^{-1}$ ). Bottles were divided into three groups with one group receiving no treatment (control) and the other two groups treated either with a bactericide or a fungicide. The bactericides evaluated in this study were streptomycin sulfate $\left(\mathrm{C}_{42} \mathrm{H}_{78} \mathrm{~N}_{14} \mathrm{O}_{24} \cdot 3 \mathrm{H}_{2} \mathrm{SO}_{4}, \mathrm{CAS} \# 3810-74-0\right)$ and bronopol $\left(\mathrm{C}_{3} \mathrm{H}_{6} \mathrm{BrNO}_{4}, \mathrm{CAS} \#\right.$ 52-51-7) obtained from Fisher Scientific. The fungicides used in this study included cycloheximide $\left(\mathrm{C}_{15} \mathrm{H}_{23} \mathrm{NO}_{4}, \mathrm{CAS} \# 66-81-9\right)$ and captan $\left(\mathrm{C}_{9} \mathrm{H}_{8} \mathrm{Cl}_{3} \mathrm{NO}_{2} \mathrm{~S}, \mathrm{CAS} \# 000133-06-2\right)$ also from Fisher Scientific. Biocides, received in dry powder formulation, were used to prepare biocide solutions. Biocides were applied at different concentrations $\left(1,2,4,8\right.$ and $16 \mathrm{mg} \mathrm{g}^{-1}$ soil), and the final volume of suspension (DEA media and dissolved biocide) in each serum bottle was adjusted with deionized water as needed to reach a final volume of $20 \mathrm{~mL}$. Each treatment was applied in triplicate.

Serum bottles were stoppered, shaken vigorously to make a slurry, then successively evacuated and flushed with ultra-high purity (UHP) $\mathrm{N}_{2}$ at least 3 times, and 
finally injected with acetylene $\left(\mathrm{C}_{2} \mathrm{H}_{2}\right)$ for a partial pressure of $10 \mathrm{kPa} \mathrm{C}_{2} \mathrm{H}_{2}$ to stop the conversion of $\mathrm{N}_{2} \mathrm{O}$ to $\mathrm{N}_{2} \cdot{ }^{13}$ Serum bottles were incubated at $25{ }^{\circ} \mathrm{C}$. Gas samples were taken from bottles headspace after 3, 8, 24 and $48 \mathrm{~h}$ of incubation, and stored in evacuated glass vials to determine $\mathrm{N}_{2} \mathrm{O}$ concentration. Based on the results of this first SI test, additional assays were conducted using only the two most effective inhibitors, but increasing their application rate to $32 \mathrm{mg} \mathrm{g}^{-1}$ soil to determine if more pronounced inhibition can be achieved at higher application rates.

\section{Assessing fungal and bacterial denitrification in plowed and no-till soils}

Based on the previous results, the SI technique was applied to different soils (PT1, NT1, and WL from Ohio; PT2 and NT2 from Indiana; Table 1) to determine the relative contribution of fungal and bacterial microflora to denitrification. Field moist $(10 \mathrm{~g})$ soil subsamples were placed in serum bottles and amended with DEA media as described before. The following biocide treatments were applied: control (no biocide), bactericide (bronopol, $16 \mathrm{mg} \mathrm{g}^{-1}$ soil), fungicide (captan, $16 \mathrm{mg} \mathrm{g}^{-1}$ soil) and BroCap (mixture of bronopol and captan, each at $16 \mathrm{mg} \mathrm{g}^{-1}$ soil). Each treatment was applied in triplicate. The final volume (DEA media and dissolved biocide) of solution in each serum bottle was 20

$\mathrm{mL}$. Serum bottles were evacuated, flushed with UHP $\mathrm{N}_{2}$, injected with $\mathrm{C}_{2} \mathrm{H}_{2}(10 \mathrm{kPa})$ as previously described. Bottles were incubated at $25^{\circ} \mathrm{C}$, and gas samples were taken from the headspace after $3,8,24,48,72,96,120,144$ and $168 \mathrm{~h}$ of incubation for determination of $\mathrm{N}_{2} \mathrm{O}$ and $\mathrm{CO}_{2}$ concentration. 


\section{Analytical methods}

Soil $\mathrm{pH}$ was measured using a soil suspension (1:2 soil to water) and an Accumet-25 $\mathrm{pH} /$ ion meter. Particle size analysis was conducted using the hydrometer method, with sodium hexametaphosphate $\left(\mathrm{Na}_{6} \mathrm{P}_{6} \mathrm{O}_{18}, 5 \%\right)$ as a dispersing agent. Finely-ground (150 $\mu \mathrm{m})$ soil samples were analyzed for total carbon and nitrogen using a Vario-Cube analyzer (Elementar Americas, Mt Laurel, $\mathrm{NJ}$ ). Concentration of $\mathrm{N}_{2} \mathrm{O}$ and $\mathrm{CO}_{2}$ in gas was measured using a Varian CP-3800 gas chromatograph (Palo Alto, CA) interfaced with a Combipal headspace auto-sampler (CTC Analytics) and equipped with a thermal conductivity detector $\left(\mathrm{CO}_{2}\right.$ detection) and an electron capture detector $\left(\mathrm{N}_{2} \mathrm{O}\right.$ detection $)$ in parallel. The stationary phase consisted of a pre-column (length: $0.3 \mathrm{~m}$; i.d.: $2 \mathrm{~mm}$ ) and an analytical column (length: $1.8 \mathrm{~m}$; i.d.: $2 \mathrm{~mm}$ ) filled with Porapak Q (80-100 mesh). Operating conditions of the gas chromatograph were as follows: carrier gas (UHP He at $20 \mathrm{~mL} \mathrm{~min}^{-1}$ for $\mathrm{CO}_{2}$, and UHP $\mathrm{N}_{2}$ at $60 \mathrm{ml} \mathrm{min}^{-1}$ for $\left.\mathrm{N}_{2} \mathrm{O}\right)$, oven temperature $\left(90{ }^{\circ} \mathrm{C}\right)$, detector temperature $\left(\mathrm{TCD}\right.$ at $150{ }^{\circ} \mathrm{C}$, and $\mathrm{ECD}$ at $\left.300{ }^{\circ} \mathrm{C}\right)$. The gas chromatograph was calibrated using certified $\mathrm{CO}_{2}$ and $\mathrm{N}_{2} \mathrm{O}$ standards obtained from Matheson Tri-Gas.

\section{Computations}

The percentage (\%) inhibition caused by a biocide was computed through comparison of gas production in biocide-treated bottles with the corresponding control (same soil) using the equation:

Inhibition $\%=\left(X_{i}-X_{\text {Control }} / X_{\text {Control }}\right) \times 100$ Where, $\mathrm{X}_{\mathrm{i}}$ and $\mathrm{X}_{\text {Control }}$ represent the amount of $\mathrm{N}_{2} \mathrm{O}$ (or $\mathrm{CO}_{2}$ ) produced during the incubation in biocide-treated bottles and control, respectively. Similar to the 
computational procedure adopted in several past studies ${ }^{22,29,30}$ the fungi to bacteria $(\mathrm{F}: \mathrm{B})$ ratio was calculated based on $\mathrm{CO}_{2}$ and $\mathrm{N}_{2} \mathrm{O}$ production in the control relative to gaseous production in soils treated with biocide. The ratio was calculated as:

$F: B=(A-B) /(A-C)$

Where, $\mathrm{A}=$ respiration measured (as cumulative $\mathrm{CO}_{2}$ concentration evolved) in the absence of inhibitors; $\mathrm{B}=$ respiration in the presence of the fungicide; and $\mathrm{C}=$ respiration in the presence of the bactericide. Since some biocides can affect non-target microorganisms, an inhibitor additivity ratio (IAR) was calculated to account for synergistic and antagonistic effects:

$I A R=[(A-B)+(A-C) /(A-D)]$

Where, $\mathrm{A}, \mathrm{B}$ and $\mathrm{C}$ are cumulative $\mathrm{CO}_{2}$ concentrations as described above, and $\mathrm{D}=$ respiration in the presence of both biocides (fungicide and bactericide). ${ }^{13,31}$ An IAR of 1 indicates no overlap in the antibiotic action on non-target organisms, and no antagonistic effect of one antibiotic on the other. An overlap is identified by an IAR $>1$ and an antagonistic effect by an IAR $<1 .{ }^{13}$

\section{Statistical analyses}

Data were first tested for normal distribution using the normality test available in the Sigma Plot software (Systat, San Jose, CA). Since most of the data were not normally distributed, Kruskal-Wallis test was used to determine the significance of the experimental factors (soil type, biocide type and application rate) on $\mathrm{N}_{2} \mathrm{O}$ and $\mathrm{CO}_{2}$ production. The Kruskal-Wallis test was followed by Mann-Whitney pairwise test when a significant difference was detected. Unless otherwise noted, statistical significance in this 
study was determined at $\alpha=0.05$. Statistical tests were conducted using PAST software (ver. 2.17c) downloaded from http://nhm2.uio.no/norlex/past/download.html (University of Oslo).

\section{Results}

\section{Selection of optimum biocides and inhibitory concentrations}

The production of $\mathrm{N}_{2} \mathrm{O}$ was observed in all treatments, but the rate of production varied significantly depending on the treatment (Figs. 1 and 2). Regardless of application rate, no inhibition of $\mathrm{N}_{2} \mathrm{O}$ production was observed with the bactericide streptomycin. Instead, streptomycin addition resulted in a slight stimulation of $\mathrm{N}_{2} \mathrm{O}$ production (Fig. 1a). In contrast, bronopol, the other bactericide used in this study, decreased $\mathrm{N}_{2} \mathrm{O}$ production at all application levels, with the most inhibitory effect observed at an application rate of 16 $\mathrm{mg} \mathrm{g}^{-1}$ soil (Fig. 1b). With regard to the fungicides, cycloheximide (Fig. 2a) was a less effective inhibitor of denitrification compared to captan (Fig. 2b). With both fungicides, the strongest inhibition was observed at the $16 \mathrm{mg} \mathrm{g}^{-1}$ soil application rate. Overall, the cumulative amount of $\mathrm{N}_{2} \mathrm{O}$ produced during the incubation was significantly $(P<0.05)$ lower with the bactericide bronopol and the fungicide captan (both at $16 \mathrm{mg} \mathrm{g}^{-1}$ ) compared to the control (Figs. 1b, 2b).

Since the most inhibitory effect of bronopol and captan was observed at the highest biocide application rate $\left(16 \mathrm{mg} \mathrm{g}^{-1}\right.$ soil $)$ used in the initial assays, additional tests were conducted by extending biocide application to $32 \mathrm{mg} \mathrm{g}^{-1}$ soil to determine whether a higher degree of inhibition can be achieved. Incubation was conducted with the same $\mathrm{NT}_{1}$ soil amended with bronopol or captan (32 $\mathrm{mg} \mathrm{g}^{-1}$ soil). Gas production was monitored 
during a 72-h period. Results showed that both biocides decreased $\mathrm{N}_{2} \mathrm{O}$ production compared to controls, but the cumulative amount of $\mathrm{N}_{2} \mathrm{O}$ produced during the incubation was statistically similar $(P>0.05)$ in bottles treated with 16 and $32 \mathrm{mg} \mathrm{g}^{-1}$ soil (Fig. 3). Since the two highest application rates $\left(16 \mathrm{mg} \mathrm{g}^{-1}\right.$ and $32 \mathrm{mg} \mathrm{g}^{-1}$ soil) of bronopol and captan produced the same degree of inhibition in $\mathrm{N}_{2} \mathrm{O}$ production (Fig. 3), the lower level (16 $\mathrm{mg} \mathrm{g}^{-1}$ soil) was used in subsequent tests to determine the relative contribution of bacterial vs fungal denitrifiers to $\mathrm{N}_{2} \mathrm{O}$ production in agricultural soils.

\section{Degree of inhibition of denitrification in different soils}

Although some minor deviations were noted in the $\mathrm{NT}_{1}$ soil, $\mathrm{N}_{2} \mathrm{O}$ evolution was generally linear during the incubation period. As expected, $\mathrm{N}_{2} \mathrm{O}$ concentration was highest in the control followed by the captan-treated soils (Fig. 4). The addition of captan marginally affected $\mathrm{N}_{2} \mathrm{O}$ production in the $\mathrm{PT}_{2}$ and $\mathrm{NT}_{2}$ soils (Fig. 4d-e), but resulted in noticeable $\mathrm{N}_{2} \mathrm{O}$ production reduction in the $\mathrm{PT}_{1}, \mathrm{NT}_{1}$ and WL soils (Fig. 4a-c). At all sampling times, both bronopol and BroCap treatments resulted in the highest inhibition in $\mathrm{N}_{2} \mathrm{O}$ production and, in all the soils investigated, cumulative $\mathrm{N}_{2} \mathrm{O}$ concentrations in these treatments were significantly $(P<0.05)$ lower than in controls.

Across treatments, addition of the bactericide bronopol resulted in $85 \pm 7 \%$ inhibition of $\mathrm{N}_{2} \mathrm{O}$ production. A similar level of inhibition ( $\left.84.7 \pm 4.7 \%\right)$ was measured when bronopol was applied concurrently with the fungicide captan. In contrast, a smaller and more variable (36 $\pm 21 \%$ ) degree of inhibition was measured with the fungicide captan, applied alone (Fig. 5). The highest $\mathrm{N}_{2} \mathrm{O}$ inhibition with captan was recorded in the $\mathrm{NT}_{1}$ soil (NT for $50 \mathrm{y}$ ). 


\section{Respiratory response of soils to biocide treatments}

A steady accumulation of $\mathrm{CO}_{2}$ was observed during the 7-day incubation period in almost all treatments (Fig. 6). As expected, $\mathrm{CO}_{2}$ production was higher in the controls than in the in the biocide-treated soils, although in the PT2 soil difference was only marginal (Fig. $6 \mathrm{~d})$. Among the control, the highest rate of $\mathrm{CO}_{2}$ accumulation was recorded in the $\mathrm{NT}_{1}$ soil (NT for 50 years) and the lowest in both PT soils (Fig. 6). The effect of biocides application on $\mathrm{CO}_{2}$ production was more variable and less pronounced than observed with $\mathrm{N}_{2} \mathrm{O}$ production. Like with $\mathrm{N}_{2} \mathrm{O}$ production, addition of the bactericide bronopol resulted in greater respiration inhibition than the other treatments $(51.4 \pm 13.3 \%$ in bronopol treatments vs $31 \pm 11.6 \%$ in BroCap and captan treatments; Fig.7). A positive relationship $\left(\mathrm{r}^{2}: 0.41, \mathrm{P}<0.01\right)$ was found between $\%$ inhibition of $\mathrm{N}_{2} \mathrm{O}$ production and $\%$ inhibition of $\mathrm{CO}_{2}$ production.

\section{Fungi:bacteria ratio}

Fungi:bacteria ratios $(\mathrm{F}: \mathrm{B})$ were calculated using both the reduction in $\mathrm{CO}_{2}$ and $\mathrm{N}_{2} \mathrm{O}$ production in biocide-treated soils relative to the controls. For all the soil and biocide treatment combinations, $\mathrm{F}: \mathrm{B}$ values were $<1$, suggesting that bacteria were the dominant group of microorganisms responsible for $\mathrm{CO}_{2}$ and $\mathrm{N}_{2} \mathrm{O}$ production in the soils tested (Table 2). The highest and lowest F:B values were observed in the $\mathrm{NT}_{1}$ and $\mathrm{PT}_{2}$ soils, respectively. 


\section{Inhibitor additivity ratio}

Data from the treatments involving the combination of bronopol and captan (both at 16 $\mathrm{mg} \mathrm{g}^{-1}$ soil; BroCap) was used to calculate IAR. Results showed that the IAR was $>1$ in all the soils tested, indicating a synergistic effect of the applied biocides (Table 3). In general, IAR values tended to be the highest in the NT and lowest in the PT soils.

\section{Discussion}

\section{Biocides efficiency in inhibiting bacterial and fungal activity}

The concentration of biocides used in past selective inhibition assays varies greatly, with optimum concentration reported in the literature ranging between 1 and $16 \mathrm{mg}$ biocide $\mathrm{g}^{-1}$ soil. $2,13,17,22,23,32$ The optimum concentration (16 mg biocide $\mathrm{g}^{-1}$ soil) found in the present study was in the upper end of that range. It has been suggested that high soil clay content can reduce the efficiency of biocides, and that higher concentrations are needed to obtain significant reduction in respiratory activity. ${ }^{22}$ Given the fine texture of the soils used in this investigation (Table 1), this reasoning would be consistent with the results. Therefore, as done in the present study, preliminary tests must be first conducted to determine optimum concentration of inhibitors for each new set of soils under investigation.

In this study, different types and levels of biocides were used to find the most effective products against denitrification and respiratory activity mediated by bacteria and fungi in agricultural soils. These products include inhibitors that were tested in some of the pioneering work to develop the selective inhibition procedure ${ }^{20}$ as well as some inhibitors introduced more recently in the literature to distinguish fungal and bacterial 
activity. ${ }^{13,17,23,24,33}$ Streptomycin, the bactericide traditionally used in SI procedure, surprisingly showed almost no inhibitory effect on the activity of bacterial denitrifiers (Fig. 1a). This result was somewhat unexpected given the large number of past investigations in which streptomycin was used as a bactericide. ${ }^{18,22,31,34}$ However, this result is in agreement with several past studies that have documented instances of inefficient inhibition of bacterial growth by streptomycin. ${ }^{2,35}$ Boyle et al. ${ }^{33}$ also reported that streptomycin was a much less effective bactericide than bronopol and oxytetracycline- $\mathrm{HCl}$ in controlling bacterial activity. Identifying the factors contributing to streptomycin inefficiency remains a challenge, but soil redox condition is likely not a contributing factor since streptomycin inefficiency has been reported in studies using both water-saturated and unsaturated soils. ${ }^{26}$

Cycloheximide was another product that exhibited surprisingly low biocidal effect. In fact, cycloheximide was the least effective of the biocides examined, and resulted in slightly higher $\mathrm{N}_{2} \mathrm{O}$ production compared to control (Fig. 2a). These results contrast with those of other studies in which cycloheximide was found to inhibit fungal activity even at low concentrations (e.g. 1-2 $\mathrm{mg} \mathrm{g}^{-1}$ soil). ${ }^{2,18}$ It has not been possible to find information in the literature to satisfactorily explain the inefficiency of cycloheximide observed in the present study. Overall, these mixed results with popular products such as streptomycin and cycloheximide underscore the need for experimentalists to first evaluate the biocides they plan to use in SI studies.

Bronopol (bactericide) and captan (fungicides) were found to be effective inhibitors of $\mathrm{N}_{2} \mathrm{O}$ production in this study. Several investigators have also successfully applied these products in past studies examining bacterial and fungal contribution to $\mathrm{N}_{2} \mathrm{O}$ 
production and respiration ${ }^{13,17,24}$. Although bronopol and captan were effective inhibitors of $\mathrm{N}_{2} \mathrm{O}$ production, some level of microbial activity was still maintained, as manifested by the slow accumulation over time of $\mathrm{N}_{2} \mathrm{O}$ and $\mathrm{CO}_{2}$ in the incubation bottles (Figs. 4 and 6). Even in the presence of both bactericide and fungicide (BroCap treatments) some gaseous production was observed. Similar observations were reported in selective inhibition studies involving desert, prairie, forest and agricultural soils ${ }^{17,18}$. This residual $\mathrm{N}_{2} \mathrm{O}$ and $\mathrm{CO}_{2}$ production in biocide-treated soils can be ascribed to the activity of surviving decomposers at the expense of metabolizable $\mathrm{C}$ and $\mathrm{N}$ released from dead microbes in the biocide-treated soils. Moreover, it needs to be noted that denitrifiers are only a small fraction $(\sim 5 \%)$ of the total soil microbial community and, therefore other microorganisms remain active even when $\mathrm{N}_{2} \mathrm{O}$ producers are inhibited. ${ }^{36}$ This line of reasoning is supported by the generally lower (1.8 times) rate of $\mathrm{CO}_{2}$ inhibition compared to that of $\mathrm{N}_{2} \mathrm{O}$ (Figs. 5 and 7).

\section{Bacteria and fungi contribution to $\mathrm{N}_{2} \mathrm{O}$ production in agricultural soils}

With all the soils tested in this study, the inhibition of $\mathrm{N}_{2} \mathrm{O}$ production was consistently stronger with addition of the bactericide bronopol than with the funcide captan (Fig. 4). These results suggest that bacteria were the main group of microorganisms contributing to denitrification in the soils investigated. The F:B ratios (Table 2) further supports this statement. A study by Herold et al. ${ }^{2}$ using arable soils also reported similar results, with fungi and bacteria contributing $18 \%$ and $54 \%$ respectively of the total $\mathrm{N}_{2} \mathrm{O}$ production. In contrast, data from Laughlin et al. ${ }^{26}$ showed a fungal dominance in $\mathrm{N}_{2} \mathrm{O}$ production in well-aerated grassland soils. The results of Seo and DeLaune ${ }^{31}$ suggested that bacteria 
were the primary drivers of denitrification under strongly-reducing conditions, whereas fungi play a greater role under aerobic and moderately-reducing conditions. Results of the present study also contrasted with those of Chen et al. ${ }^{28}$ that documented higher fungal contribution than bacteria to $\mathrm{N}_{2} \mathrm{O}$ production in soils from various ecosystems. It is unclear that the $\mathrm{pH}$ (5.3-6.5 vs 5.5-7.4; Table 1) and texture (sandy vs clay-loam) of the soils evaluated by Chen et al. ${ }^{28}$, the antibiotics used (streptomycin/cycloheximide vs bronopol/captan in the present study) and their incubation method ( $<90 \%$ water-filled pore space vs fully anoxic in the present study) may contribute to these contrasting results. Therefore, in light of these considerations and the variety of methodologies adopted in past studies, it is prudent to caution against generalization at this point. Therefore, future studies should examine these factors and, most importantly, the effect of redox status on the partitioning of $\mathrm{N}_{2} \mathrm{O}$ production between fungi and bacteria in agricultural soils.

\section{Tillage practices and $\mathrm{N}_{2} \mathrm{O}$ production partitioning between soil bacteria and fungi}

Under NT management, soils are less disturbed in comparison to PT and are generally covered with crop residue cover. This contributes to higher moisture content in NT, a soil environment that is likely favorable to the proliferation of denitrifying microbes. ${ }^{37,38} \mathrm{In}$ addition, fungi are more likely to succeed in soil systems that are left undisturbed, allowing for the development of fungal hyphae which are in contact with crop residue on the land surface. ${ }^{11}$ In contrast, because of soil mixing and the direct contact between decomposers and substrates in PT soil systems, the microbial community is generally dominated by bacteria. ${ }^{17}$ 
Despite its wide use in soil biochemistry research, the SI method has inherent shortcomings. The IAR ratios provide a way to assess the validity of $\mathrm{F}: \mathrm{B}$ ratios derived from the method. IAR values close to 1 are usually taken as an indication of the accuracy F:B estimations. ${ }^{31}$ Values for IAR found in this study are in the same range as those reported in several past investigations. ${ }^{13,35}$ These deviations have generally been ascribed to inhibition of non-target microorganisms by the biocides applied. ${ }^{17}$

The $\mathrm{F}: \mathrm{B}$ ratios for $\mathrm{N}_{2} \mathrm{O}$ production were less than 1, indicating the dominance of bacteria as $\mathrm{N}_{2} \mathrm{O}$ producers in the soils tested. This conclusion is at variance with the hypothesis of the study regarding fungal dominance of NT soils. The $\mathrm{N}_{2} \mathrm{O}$ inhibition data (Fig. 5) showed that, among the soils tested, the fungicide captan induced its highest level $(66 \%)$ of denitrification inhibition in the $\mathrm{NT}_{1}$ soil (50 y under NT). In comparison, the inhibition measured in the mid-term (11 y) NT soil was only $18 \%$ (Fig. 5). Similarly, the highest $\mathrm{F}: \mathrm{B}$ ratios (computed using either $\mathrm{CO}_{2}$ or $\mathrm{N}_{2} \mathrm{O}$ production data) were measured in the NT1 soil (Table 2), although difference was not significant. This trend could indicate the evolution of a larger population of fungal denitrifiers in agricultural soils with longer duration of no-till management (e.g. $\mathrm{NT}_{1}$ ). Chronosequence studies, using soils under NT for varying length of time, are needed to test the merit of that suggestion.

\section{Conclusions}

One of the objectives of this study was to identify the types and levels of biocide leading to optimum inhibition of denitrification in agricultural soils. Streptomycin and cycloheximide, the biocides most commonly used in selective inhibition assays, hardly resulted in any inhibition of $\mathrm{N}_{2} \mathrm{O}$ production. In fact, in some of the soils, streptomycin 
stimulated the process. The reason for this lack of inhibition remains to be elucidated. Captan and bronopol, however, inhibited $\mathrm{N}_{2} \mathrm{O}$ and $\mathrm{CO}_{2}$ production, with an optimum concentration of $16 \mathrm{mg} \mathrm{g}^{-1}$ for both biocides. Fungi:bacteria ratios smaller than 1 were measured in all the soils tested, suggesting that bacteria were the dominant $\mathrm{N}_{2} \mathrm{O}$ producers in the soils investigated. Although the difference was not significant, this ratio was highest in the long-term NT soil $\left(\mathrm{NT}_{1}\right)$, suggesting a progressively greater role for fungal denitrifiers in the denitrification process with longer NT duration.

\section{Acknowledgements}

Funding for this study was provided through USDA-NRI grant 2009-35112-05213. Authors thank Mike Starkey for granting access to his fields. Field and laboratory assistance of Sandra Ndichu, Austin Taylor, Reina Hiramatsu and Erika Harbison is gratefully acknowledged.

\section{References}

1 J.M. Bremner, Sources of nitrous oxide in soils, Nutr. Cycl. Agroecosys., 1997, 49, 7-16.

2 M.B. Herold, E.M. Baggs and T.J. Daniell, Fungal and bacterial denitrification are differently affected by long-term $\mathrm{pH}$ amendment and cultivation of arable soil, Soil Biol. Biochem., 2012, 54, 25-35.

3 Q. Qiu, L. Wu, Z. Ouyang, B. Li and Y. Xu, Effects of different forms of plantderived organic matter on nitrous oxide emissions, Environ. Sci.: Processes Impacts, 2016, 18, 854-862. 
4 R. Ruser, H. Flessa, R. Russow, G. Schmidt, F. Buegger and J.C. Munch, Emission of $\mathrm{N}_{2} \mathrm{O}, \mathrm{N}_{2}$ and $\mathrm{CO}_{2}$ from soil fertilized with nitrate: effect of compaction, soil moisture and rewetting, Soil Biol. Biochem., 2006, 38, 263-274.

5 H. Harada, H. Kobayashi and H. Shindo, Reduction in greenhouse gas emissions by no-tillage rice cultivation in Hachirogata polder, northern Japan: Life-cycle inventory analysis, Soil Sci. Plant Nutr., 2007, 53, 668-677.

6 Metay, R. Oliver, E. Scopel, J.M. Douzet, J. Aloisio, A. Moreira, F. Maraux, B.J. Feigl and $\mathrm{C}$. Feller, $\mathrm{N}_{2} \mathrm{O}$ and $\mathrm{CH}_{4}$ emissions from soils under conventional and no-tillage management practices in Goiania (Cerrados, Brazil), Geoderma, 2007, 141, 78-88.

7 M. Alvear, A. Rosas, J.L. Rouanet and F. Borie, Effects of three soil tillage systems on biological activities in an Ultisol from southern Chile, Soil Till. Res., 2005, 82, 195-202.

8 K. Regina and L. Alakukku, Greenhouse gas fluxes in varying soils under conventional and no-tillage practices, Soil Till. Res., 2010, 109, 144-152.

9 J.W. Elder and R. Lal, Tillage effects on gaseous emissions from an intensively farmed organic soil in North Central Ohio, Soil Till. Res., 2008, 98, 45-55.

10 D.A.N. Ussiri, R. Lal and M.K. Jarecki, Nitrous oxide and methane emissions from long-term tillage under a continuous corn cropping system in Ohio, Soil Till. Res., 2009, 104:247-255.

11 S.D. Frey, SE.T. Elliott and K. Paustian, Bacterial and fungal abundance and biomass in conventional and no-tillage agroecosystems along two climate gradients, Soil Biol. Biochem., 1999, 31, 573-585. 
12 E.A. Holland and D.C. Coleman, Litter placement effect on microbial and organic matter dynamics in an agroecosystem, Ecology, 1987, 68, 425-433.

13 V.L. Bailey, J.L. Smith and H. Bolton, Novel antibiotics as inhibitors for the selective respiratory inhibition method of measuring fungal:bacterial ratios in soil, Biol. Fertil. Soils., 2003, 38, 154-160.

14 P. Lienhard, F. Tivet, A. Chabanne, S. Dequiedt, M. Lelievre, S. Sayphoummie, B. Leudphanane, N.C. Prevost-Boure, L. Seguy, P.A. Maron and L. Ranjard, Notill and cover crops shift soil microbial abundance and diversity in Laos tropical grasslands, Agron. Sustain. Dev., 2013, 33, 375-384.

15 M.H. Beare, R.W. Parmelee, P.F. Hendrix, W. Cheng, D.C. Coleman and D.A. Crossley, Microbial and faunal interactions and effects on litter nitrogen and decomposition in agroecosystems, Ecol. Monogr., 1992, 62, 569-591.

16 E.J. Kladivko, Tillage systems and soil ecology, Soil Till. Res., 2001, 61, 61-76.

17 V.L. Bailey, J.L. Smith and H. Bolton, Fungal-to-bacterial ratios in soils investigated for enhanced C sequestration, Soil Biol. Biochem., 2002, 34, 9971007.

18 C.L. Crenshaw, C. Lauber, R.L. Sinsabaugh and L.K. Stavely, Fungal control of nitrous oxide production in semiarid grassland, Biogeochemistry, 2008, 87, 17-27.

$19 \mathrm{H}$. Velvis, Evaluation of the selective respiratory inhibition method for measuring the ratio of fungal:bacterial activity in acid agricultural soils, Biol. Fertil. Soils, 1997, 25, 354-360.

20 J.P.E. Anderson and K.H. Domsch, Quantification of bacterial and fungal contributions to soil respiration, Arch. Microbiol., 1973, 93, 113-127. 
21 J.P.E. Anderson and K.H. Domsch, Measurement of bacterial and fungal contributions to respiration of selected agricultural and forest soils, Can. J. Microbiol., 1975, 21, 314-322.

22 J. Alphei, M. Bonkowski and S. Scheu, Application of the selective inhibition method to determine bacterial:fungal ratios in three beechwood soils rich in carbon- Optimization of inhibitor concentrations, Biol. Fertil. Soils., 1995, 19, 173-176.

23 J. Rousk, L.A. Demoling and E. Baath, Contrasting short-term antibiotic effects on respiration and bacterial growth compromises the validity of the selective respiratory inhibition technique to distinguish fungi and bacteria, Microb. Ecol., 2009, 58, 75-85.

24 M.B. Sassi, J. Dollinger, P. Renault, A. Tlili and A. Berard, The FungiResp method: An application of the MicroResp method to assess fungi in microbial communities as soil biological indicators, Ecological Indicators, 2012, 23, 482490.

25 Y. Yanai, K.Toyota, T. Morishita, F. Takakai, R. Hatano, S.H. Limin, U. Darung and $\mathrm{S}$. Dohong, Fungal $\mathrm{N}_{2} \mathrm{O}$ production in an arable peat soil in Central Kalimantan, Indonesia, Soil Sci. Plant Nutr., 2007, 53, 806-811.

26 J. Laughlin, R.J. Stevens, C. Muller and C.J. Watson, Evidence that fungi can oxidize $\mathrm{NH}_{4}{ }^{+}$to $\mathrm{NO}_{3}{ }^{-}$in a grassland soil. Eur. J. Soil Sci., 2009, 59, 285-291.

27 N.D. Ananyeva, E.A, Stolnikova, E.A. Susyan and A.K. Khodzhaeva, The fungal and bacterial biomass (selective inhibition) and the production of $\mathrm{CO}_{2}$ and $\mathrm{N}_{2} \mathrm{O}$ by 
soddy-podzlic soils of postagrogenic biogeocenoses, Eurasian Soil Sci., 2010, 43, 1287-1293.

28 H. Chen, N.V. Mothapo and W. Shi, The significant contribution of fungi to soil $\mathrm{N}_{2} \mathrm{O}$ production across diverse ecosystems, Appl. Soil Ecol., 2014, 73, 70-77.

29 M.H. Beare, C.L. Neely, D.C. Coleman and W.L. Hargrove, A substrate induced respiration (SIR) method for measurement of fungal and bacterial biomass on plant residue, Soil Biol. Biochem., 1990, 22, 585-594.

30 H. Chen, N.V. Mothapo and W. Shi, Fungal and bacterial $\mathrm{N}_{2} \mathrm{O}$ production regulated by soil amendments of simple and complex substrates, Soil Biol. Biochem., 2015, 84, 116-126.

31 D.C. Seo and R.D. DeLaune, Effects of redox conditions on bacterial and fungal biomass and carbon dioxide production in Louisiana coastal swamp forest sediment, Sci. Total Environ., 2010, 17, 2623-2631.

32 J. Laughlin and R.J. Stevens, Evidence for fungal dominance of denitrification and codenitrification in a grassland soil, Soil Sci. Soc. Am. J., 2002, 66, 15401548.

33 A.A. Boyle, R.R. Yarwood, P.J. Bottomley and D.D. Myrold, Bacterial and fungal contributions to soil nitrogen cycling under Douglas fir red alder at two sites in Oregon, Soil Biol. Biochem., 2008, 40, 443-451.

34 N.C. Johnson, D.L. Rowland, L. Corkidi, L.M. Egerton-Warburton and E.B. Allen, Nitrogen enrichment alters mycorrhizal allocation at five mesic to semiarid grasslands, Ecology, 2003, 84, 1895-1908. 
35 T. Nakamato and S. Wakahara, Development of substrate induced respiration (SIR) method combined with selective inhibition for estimating fungal and bacterial biomass in humic andosols, Plant Prod. Sci., 2004, 7, 70-76.

36 S. Henry, D. Bru, B. Stres, S. Hallet and L. Philippot, Quantitative detection of the nosZ gene, encoding nitrous oxide reductase, and comparison of the abundance of 16s rRNA, narG, nirK, and nosZ genes in soils, Appl. Environ. Microbiol., 2006, 72, 5181-5189.

37 E.L. Bateman and E.M. Baggs, Contribution of nitrification and denitrification to $\mathrm{N}_{2} \mathrm{O}$ emissions from soils at different water-filled pore space, Biol. Fertil. Soils., 2005, 41, 379-388.

38 K.T. Imberger and C.Y. Chiu, Spatial changes of soil fungal and bacterial biomass from a sub-alpine coniferous forest to grassland in a humid, subtropical region, Biol. Fertil. Soils, 2001, 33, 105-110.

Table 1 Chemical properties of soils $(0-10 \mathrm{~cm})$ used in the study

\begin{tabular}{lccccc}
\hline $\begin{array}{l}\text { Location of } \\
\text { sampling sites }\end{array}$ & $\begin{array}{c}\text { Tillage } \\
\text { practice }\end{array}$ & $\mathrm{pH}$ & $\begin{array}{c}\text { Total C } \\
\left(\mathrm{g} \mathrm{C} \mathrm{kg}^{-1} \mathrm{soil}\right)\end{array}$ & $\begin{array}{c}\text { Total N } \\
\left(\mathrm{g} \mathrm{N} \mathrm{kg}^{-1} \text { soil }\right)\end{array}$ & Soil texture \\
\hline $\begin{array}{l}\text { S. Charleston } \\
\text { (Ohio) }\end{array}$ & $\mathrm{PT}_{1}$ & 7.16 & $12.6 \pm 1.00$ & $1.5 \pm 0.23$ & Silt clay loam \\
& $\mathrm{NT}_{1}$ & 6.14 & $21.2 \pm 0.20$ & $2.0 \pm 0.50$ & Silt clay loam \\
& $\mathrm{WL}$ & 5.54 & $31.4 \pm 1.20$ & $2.5 \pm 0.31$ & Silt loam \\
Starkey farms & $\mathrm{PT}_{2}$ & 6.41 & $13.3 \pm 2.3$ & $1.9 \pm 0.60$ & Silt loam \\
(Indiana) & $\mathrm{NT}_{2}$ & 7.42 & $18.5 \pm 1.6$ & $1.7 \pm 0.20$ & Silt loam \\
\hline
\end{tabular}


Table 2 Fungi:bacteria ratio (F:B) based on the cumulative $\mathrm{CO}_{2}$ and $\mathrm{N}_{2} \mathrm{O}$ concentration during a 168-h incubation of soils treated with either bronopol (bactericide) or captan (fungicide) applied at a rate of $16 \mathrm{mg} \mathrm{g}^{-1}$ soil. Soils used in these assays were from sites under plow-till ( $\mathrm{PT}_{1}$ and $\left.\mathrm{PT}_{2}\right)$, long-term (50 years, $\left.\mathrm{NT}_{1}\right)$, and medium-term no-till (11 years, $\mathrm{NT}_{2}$ ). Soils from a woodlot (WL) were also incubated for comparison

\begin{tabular}{ccc}
\hline Soil type & $\mathrm{F}: \mathrm{B}$ & $\mathrm{F}: \mathrm{B}$ \\
& (based on $\mathrm{CO}_{2}$ concentration) & (based on $\mathrm{N}_{2} \mathrm{O}$ concentration) \\
\hline $\mathrm{PT}_{1}$ & $0.50 \pm 0.21$ & $0.50 \pm 0.13$ \\
$\mathrm{NT}_{1}$ & $0.67 \pm 0.31$ & $0.87 \pm 0.18$ \\
$\mathrm{WL}$ & $0.45 \pm 0.18$ & $0.46 \pm 0.24$ \\
$\mathrm{PT}_{2}$ & $0.43 \pm 0.22$ & $0.24 \pm 0.09$ \\
$\mathrm{NT}_{2}$ & $0.49 \pm 0.15$ & $0.22 \pm 0.11$ \\
\hline
\end{tabular}

Table 3 Inhibitor additivity ratio (IAR) based on the cumulative $\mathrm{CO}_{2}$ concentration during a 168-h incubation of soils treated with either bronopol (bactericide) or captan (fungicide) applied at a rate of $16 \mathrm{mg} \mathrm{g}^{-1}$ soil. Soils used in these assays were from sites under plow-till ( $\mathrm{PT}_{1}$ and $\left.\mathrm{PT}_{2}\right)$, long-term (50 years, $\left.\mathrm{NT}_{1}\right)$, and medium-term no-till (11 years, $\mathrm{NT}_{2}$ ). Soils from a woodlot (WL) were also incubated for comparison

\begin{tabular}{cc}
\hline Soil type & IAR \\
\hline $\mathrm{PT}_{1}$ & $1.02 \pm 0.18$ \\
$\mathrm{NT}_{1}$ & $1.80 \pm 0.51$ \\
$\mathrm{WL}$ & $1.46 \pm 0.11$ \\
$\mathrm{PT}_{2}$ & $1.22 \pm 0.35$ \\
$\mathrm{NT}_{2}$ & $1.71 \pm 0.24$ \\
\hline
\end{tabular}


Fig. 1 Nitrous oxide production in control and soils treated with different concentrations of bactericide, (a) control vs. streptomycin, (b) control vs. bronopol. Error bars represent SD from a mean of three replicates.

Fig. 2 Nitrous oxide production in control and soils treated with different concentrations of fungicide, (a) control vs. cycloheximide, (b) control vs. captan. Error bars represent SD from a mean of three replicates.

Fig. 3 Nitrous oxide production in control and soils treated with different concentrations of biocides, (a) control vs. bronopol, (b) control vs. captan. Error bars represent SD from a mean of three replicates.

Fig. 4 Nitrous oxide production in control and soils treated with either bronopol (bactericide), captan (fungicide) or their mixture (BroCap). Biocide was applied at a rate of $16 \mathrm{mg} \mathrm{g}^{-1}$ soil. Soils used in these assays were from sites under plow-till ( $\mathrm{PT}_{1}$ and $\mathrm{PT}_{2}$ ), long-term (50 years, $\mathrm{NT}_{1}$ ), and medium-term no-till (11 years, $\mathrm{NT}_{2}$ ). Soils from a woodlot (WL) were also incubated for comparison. Data are presented in the following graph panels: (a) $\mathrm{PT}_{1}$, (b) $\mathrm{NT}_{1}$ (50 years), (c) WL, (d) $\mathrm{PT}_{2}$, and (e) $\mathrm{NT}_{2}$ (11 years). Error bars represent SD from a mean of three replicates.

Fig. 5 Percent inhibition (\%) of nitrous oxide production in soils treated with either bronopol (bactericide), captan (fungicide) or their mixture (BroCap). Biocide was applied at a rate of $16 \mathrm{mg} \mathrm{g}^{-1}$ soil. Soils used in these assays were from sites under plow-till ( $\mathrm{PT}_{1}$ and $\mathrm{PT}_{2}$ ), long-term (50 years, $\mathrm{NT}_{1}$ ), and medium-term no-till (11 years, $\mathrm{NT}_{2}$ ). Soils from a woodlot (WL) were also incubated for comparison. Data are presented in the following graph panels: (a) $\mathrm{PT}_{1}$, (b) $\mathrm{NT}_{1}$ (50 years), (c) WL, (d) $\mathrm{PT}_{2}$, and (e) $\mathrm{NT}_{2}$ (11 years). Within a biocide treatment, bars are labelled with different letters to indicate a significant difference between tillage practices. Error bars represent SD from a mean of three replicates.

Fig. 6 Carbon dioxide production in control and soils treated with either bronopol (bactericide), captan (fungicide) or their mixture (BroCap). Biocide was applied at a rate of $16 \mathrm{mg} \mathrm{g}^{-1}$ soil. Soils used in these assays were from sites under plow-till ( $\mathrm{PT}_{1}$ and $\mathrm{PT}_{2}$ ), long-term (50 years, $\mathrm{NT}_{1}$ ), and medium-term no-till (11 years, $\mathrm{NT}_{2}$ ). Soils from a woodlot (WL) were also incubated for comparison. Data are presented in the following graph panels: (a) $\mathrm{PT}_{1}$, (b) $\mathrm{NT}_{1}$ (50 years), (c) WL, (d) $\mathrm{PT}_{2}$, and (e) $\mathrm{NT}_{2}$ (11 years). Error bars represent SD from a mean of three replicates.

Fig. 7 Percent inhibition (\%) of carbon dioxide production in soils treated with either bronopol (bactericide), captan (fungicide) or their mixture (BroCap). Biocide was applied at a rate of $16 \mathrm{mg} \mathrm{g}^{-1}$ soil. Soils used in these assays were from sites under plow-till ( $\mathrm{PT}_{1}$ and $\mathrm{PT}_{2}$ ), long-term (50 years, $\mathrm{NT}_{1}$ ), and medium-term no-till (11 years, $\mathrm{NT}_{2}$ ). Soils from a woodlot (WL) were also incubated for comparison. 
Data are presented in the following graph panels: (a) $\mathrm{PT}_{1}$, (b) $\mathrm{NT}_{1}$ (50 years), (c) WL, (d) $\mathrm{PT}_{2}$, and (e) $\mathrm{NT}_{2}$ (11 years). Within a biocide treatment, bars are labelled with different letters to indicate a significant difference between tillage practices. Error bars represent SD from a mean of three replicates. 